\author{
KRZYSZTOF KOlEndA ${ }^{1}$, TOMASZ SkAwiŃSKI ${ }^{1}$, MikOŁAJ KACZMARSKI ${ }^{2}$
}

\author{
Uniwersytet Wrockawski \\ Sienkiewicza 21, 50-335 Wrockaw \\ ${ }^{2}$ Zakład Zoologii \\ Instytut Zoologii \\ Uniwersytet Przyrodniczy $w$ Poznaniu \\ Wojska Polskiego 71c, 60-625 Poznań \\ E-mail: krzysztof.kolenda@uwr.edu.pl
}

${ }^{1}$ Zakład Biologii Ewolucyjnej i Ochrony Kręgowców

\title{
PRZEGLĄD „NOWYCH” GATUNKÓW PŁAZÓW I GADÓW WYSTĘPUJĄCYCH W POLSCE
}

\section{WSTEP}

Wydawać by się mogło, że na terenach najlepiej poznanych przyrodniczo (takich jak Europa Środkowa) sprawy tak podstawowe, jak liczba gatunków występujacych na obszarze danego kraju, sa dobrze zbadane. Upowszechnienie badań molekularnych doprowadziło jednak do rewolucji w systematyce zwierzact. Dotyczyła ona nie tylko zmiany naszych pogląów na temat pokrewieństw, ale też skutkowała rozpoznaniem tzw. „ukrytej różnorodności"; wiele taksonów, które wcześniej klasyfikowano jako gatunki, okazało się na tyle różnorodnych genetycznie, że zasadne stało się podzielenie ich na kilka odrębnych gatunków (WIENS 2008). Często do rangi gatunku podnoszono dawne podgatunki, ustanowione na podstawie stosunkowo niewielkich różnic morfologicznych (GVOŽDíK i współaut. 2013, PABIJAN i współaut. 2017). W zwiazku $z$ aktualizacja rozmieszczenia gatunków i wyodrębnieniem nowych taksonów doszło do znacznych zmian $\mathrm{w}$ zrozumieniu bogactwa gatunkowego $\mathrm{w}$ zachodniej Palearktyce. Tym samym w strefie umiarkowanych szerokości geograficznych wyznaczono aż osiem ważnych punktów/ stref różnorodności gatunkowej płazów, majacych duże implikacje dla ich ochrony (DUFRESNES 2018). Dodatkowo, w dobie obecnych zmian klimatycznych, wiele gatunków, zwłaszcza ciepłolubnych, poszerza swoje zasięgi występowania, stąd moga pojawiać się na terenach wcześniej przezeń niezasiedlanych (ARAÚJO i współaut. 2006). W tego typu ekspansjach często swoja rolę odgrywa czlowiek, czy to poprzez celowe wypuszczanie zwierzat do środowiska naturalnego (np. przez hodowców), źle zaplanowane projekty czynnej ochrony czy też nieświadomy transport na nowe obszary (DUBEY i współaut. 2019, SANTOS i współaut. 2019). Niejednokrotnie ustalenie, czy dany gatunek jest rodzimy dla danego terenu, czy też np. został tam wypuszczony, przysparza wielu trudności (WIRGA i MAJTYKA 2013, DUDEK 2014).

Powyższe powody przyczynily się do opisania w ostatnich latach nowych dla Polski gatunków herpetofauny. Jednak brak znajomości szczegółów na temat pojawienia się lub wykrycia poszczególnych gatunków w naszym kraju spowodował, że w literaturze, nawet tej najnowszej, pojawiaja się sprzeczne informacje na temat liczby krajowych gatunków płazów i gadów. Przykładowo, w monografii Fauna Polski. Charakterystyka $i$ wykaz gatunków. Tom 4 wymienionych jest 30 gatunków, w tym 18 płazów (FORMICKI i współaut. 2014) i 12 gadów (SzYNDLAR i BORCZYK 2014), GIERLIŃSKI i współaut. (2015) podaja ich 31 (19 płazów i 12 gadów), natomiast od 2014 r. w Polsce ochronie gatunkowej podlega 18 gatunków płazów i 10 gatunków gadów (ROZPORZĄDZENIE 2014, 2016). Dopiero w wydanym w połowie $2018 \mathrm{r}$. Atlasie płazów i gadów Polski pod redakcja 
Tabela 1. „Nowe” gatunki płazów i gadów stwierdzone w Polsce.

\begin{tabular}{|c|c|c|c|c|c|c|}
\hline \multirow{2}{*}{$\begin{array}{l}\text { Nazwa łaciń- } \\
\text { ska }\end{array}$} & \multirow{2}{*}{$\begin{array}{l}\text { Nazwa } \\
\text { polska }\end{array}$} & \multirow{2}{*}{$\begin{array}{l}\text { Pozycja sys- } \\
\text { tematyczna }\end{array}$} & \multirow{2}{*}{ Status gatunku } & \multicolumn{2}{|c|}{ Status ochronny w Polsce } & \multirow{2}{*}{$\begin{array}{l}\text { Gatunek po- } \\
\text { dobny }\end{array}$} \\
\hline & & & & aktualny & proponowany & \\
\hline $\begin{array}{l}\text { Hyla orien- } \\
\text { talis }\end{array}$ & $\begin{array}{l}\text { rzekotka } \\
\text { wschod- } \\
\text { nia }\end{array}$ & $\begin{array}{l}\text { Amphibia, } \\
\text { Hylidae }\end{array}$ & $\begin{array}{l}\text { „nowy” gatunek ro- } \\
\text { dzimy }\end{array}$ & brak & ochrona ścisła & Hyla arborea \\
\hline $\begin{array}{l}\text { Anguis col- } \\
\text { chica }\end{array}$ & $\begin{array}{l}\text { padalec } \\
\text { kolchidz- } \\
\text { ki }\end{array}$ & $\begin{array}{l}\text { Reptilia, } \\
\text { Anguidae }\end{array}$ & $\begin{array}{l}\text { „nowy” gatunek ro- } \\
\text { dzimy }\end{array}$ & brak & ochrona częściowa & Anguis fragilis \\
\hline $\begin{array}{l}\text { Bufotes va- } \\
\text { riabilis }\end{array}$ & - & $\begin{array}{l}\text { Amphibia, } \\
\text { Bufonidae }\end{array}$ & $\begin{array}{l}\text { „nowy” gatunek ro- } \\
\text { dzimy o niepewnym } \\
\text { statusie taksono- } \\
\text { micznym }\end{array}$ & brak & $\begin{array}{l}\text { brak do czasu roz- } \\
\text { strzygnięcia statu- } \\
\text { su gatunku }\end{array}$ & Bufotes viridis \\
\hline $\begin{array}{l}\text { Pelophylax } \\
\text { kurtmuelleri }\end{array}$ & $\begin{array}{l}\text { żaba bał- } \\
\text { kańska }\end{array}$ & $\begin{array}{l}\text { Amphibia, } \\
\text { Ranidae }\end{array}$ & $\begin{array}{l}\text { gatunek o niepew- } \\
\text { nym pochodzeniu } \\
\text { i statusie taksono- } \\
\text { micznym }\end{array}$ & brak & $\begin{array}{l}\text { brak do czasu roz- } \\
\text { strzygnięcia statu- } \\
\text { su gatunku }\end{array}$ & $\begin{array}{l}\text { Pelophylax ridi- } \\
\text { bundus }\end{array}$ \\
\hline $\begin{array}{l}\text { Podarcis } \mathrm{mu}^{-} \\
\text {ralis }\end{array}$ & $\begin{array}{l}\text { murówka } \\
\text { zwyczaj- } \\
\text { na }\end{array}$ & $\begin{array}{l}\text { Reptilia, } \\
\text { Lacertidae }\end{array}$ & $\begin{array}{l}\text { gatunek o niepew- } \\
\text { nym pochodzeniu }\end{array}$ & brak & $\begin{array}{l}\text { brak do czasu roz- } \\
\text { strzygnięcia statu- } \\
\text { su gatunku }\end{array}$ & Zootoca vivipara \\
\hline $\begin{array}{l}\text { Natrix tessel- } \\
\text { lata }\end{array}$ & $\begin{array}{l}\text { zaskro- } \\
\text { niec ry- } \\
\text { bołów }\end{array}$ & $\begin{array}{l}\text { Reptilia, } \\
\text { Colubridae }\end{array}$ & $\begin{array}{l}\text { gatunek o niepew- } \\
\text { nym pochodzeniu i } \\
\text { występowaniu }\end{array}$ & $\begin{array}{l}\text { ochrona } \\
\text { ścisła }\end{array}$ & $\begin{array}{l}\text { usunąć z ochrony } \\
\text { ścisłej do czasu } \\
\text { rozstrzygnięcia sta- } \\
\text { tusu gatunku }\end{array}$ & Natrix natrix \\
\hline $\begin{array}{l}\text { Trachemys } \\
\text { scripta }\end{array}$ & $\begin{array}{l}\text { żółw } \\
\text { ozdobny }\end{array}$ & $\begin{array}{l}\text { Reptilia, } \\
\text { Emydidae }\end{array}$ & gatunek obcy & $\begin{array}{l}\text { brak/gatu- } \\
\text { nek inwa- } \\
\text { zyjny }\end{array}$ & $\begin{array}{l}\text { brak/gatunek inwa- } \\
\text { zyjny }\end{array}$ & Emys orbicularis \\
\hline
\end{tabular}

GŁowACIŃSKIEGO i SURY podjęto próbę omówienia nowo opisanych dla Polski gatunków.

W niniejszym artykule postaramy się usystematyzować informacje dotyczące „nowych" gatunków płazów i gadów w faunie Polski. Przedstawimy również warte przypomnienia historyczne dane na temat ich występowania w obecnych granicach Polski. Poniżej klasyfikujemy te gatunki do kilku wzajemnie niewykluczajacych się kategorii (Tabela 1): (i) „nowych" gatunków rodzimych, czyli powstałych w wyniku decyzji taksonomicznych (np. podniesienia dawnego podgatunku do rangi odrębnego gatunku), (ii) o niepewnym pochodzeniu (czyli takich, co do których brak wystarczającej ilości informacji, by stwierdzić, czy sa rodzime, czy obce), (iii) o niepewnym występowaniu na obszarze Polski, (iv) o niepewnym statusie taksonomicznym, (v) gatunków obcych.

\section{RZEKOTKA WSCHODNIA HYLA} ORIENTALIS (BEDRIAGA, 1890)

Rodzina rzekotkowatych Hylidae stanowi jedna $z$ największych w obrębie rzędu płazów bezogonowych Anura. Zaliczana do nich rzekotka drzewna Hyla arborea (Linnaeus, 1758), szeroko występujaca w Europie, w tym w Polsce, jeszcze do niedawna uważana była za gatunek monotypowy. Było to spowodowane przede wszystkim brakiem badań molekularnych nad filogeneza rzekotek wystepujacych w zachodniej Palearktyce. Zmieniło się to w 2008 r., gdy odkryto, że rzekotka drzewna jest tak naprawdę grupa przynajmniej kilku gatunków kryptycznych, $z$ czego $H$. arborea (sensu stricto) wystepuje w Europie Zachodniej i na Bałkanach, natomiast Europę Wschodnia zasiedla rzekotka wschodnia $H$. orientalis (Ryc. 1A), która wyodrębniła się w pliocenie i stanowi odrębny gatunek (STÖcK i współaut. 2008, GVOžDÍK i współaut. 2010a). Te zaskakujace wyniki sugerowały możliwe występowanie rzekotki wschodniej także w Polsce, co zostało potwierdzone kilka lat później (STÖCK i współaut. 2012). Szczegółowe informacje dotyczące rozmieszczenia obu gatunków w Polsce północnej poznaliśmy jednak dopiero w 2016 r. Okazało się, zgodnie $z$ wcześniejszymi przewidywaniami (STÖcK i współaut. 2012), że rzekotka drzewna występuje w zachodniej, a rzekotka wschodnia we wschodniej Pol- 

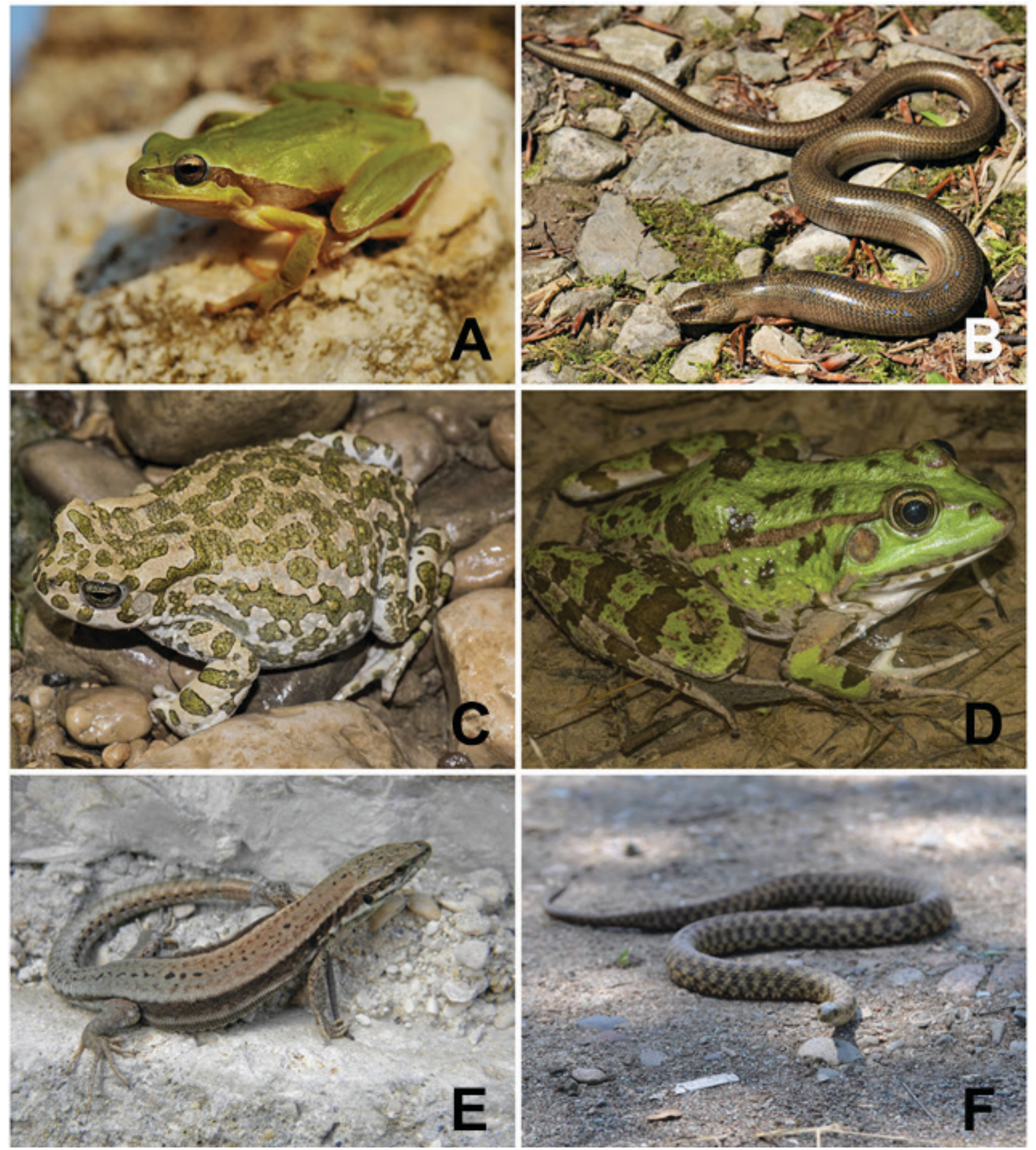

Ryc. 1. Rzekotka wschodnia Hyla orientalis (A), padalec kolchidzki Anguis colchica (B), ropucha Bufotes variabilis (C), żaba bałkańska Pelophylax kurtmuelleri (D), murówka zwyczajna Podarcis muralis (E), zaskroniec rybołów Natrix tessellata (F).

Fot. Daniel Jablonski (A-D), Jan Kaczmarek (E), Natalia Kuśmierek (F).

sce, zaś granica ich występowania jest Wisła (DUFRESNES i współaut. 2016). Granica ta nie jest jednak zbyt szczelna, ponieważ dolina Noteci rzekotka wschodnia przekroczyła Wisłę, natomiast po zachodniej stronie Pojezierza Mazurskiego występują też rzekotki drzewne. W miejscach styku obu gatunków dochodzi do ich swobodnego krzyżowania się, w wyniku czego powstaja różne formy mieszańcowe (DUfRESNEs i współaut. 2016).

Jak już wcześniej wspomniano, występujące w Polsce rzekotki należą do gatunków kryptycznych (ale nie siostrzanych), co oznacza, że nie ma między nimi wyraźnych 
różnic w morfologii i odgłosach godowych (SPEYBROECK i współaut. 2010), a najpewniejszą metoda ich rozróżniania jest użycie odpowiednich markerów genetycznych. Między osobnikami obu gatunków zamieszkującymi Polskę występują nieznaczne różnice morfologiczne: rzekotka drzewna charakteryzuje się m.in. mniejszą długościa ciała, szerszą głowa oraz krótszym podudziem, jednak te $\mathrm{i}$ inne cechy sa mało przydatne do rozróżniania gatunków w terenie (PROFUs i MAJTYKA 2018, Majtyka i Borczyk, dane niepubl.). Dodatkowo sytuacje komplikuje ich krzyżowanie się w miejscach wspólnego występowania. Zasadne wydaje się zatem wspólne umieszczenie obu gatunków rzekotek w Atlasie... na jednej mapie ich rozmieszczenia (PROFus i MAJTYKA 2018). Biorac pod uwagę powyższe, dziwi fakt, że chociaż rzekotka drzewna objęta jest ochrona ścisła, jej bliźniaczy gatunek, o którego występowaniu na wschodzie kraju wiemy od 2012 r. (STöcK i współaut, 2012) nie doczekał się ochrony prawnej ani w stosownym rozporządzeniu z 2014 r., ani w jego kolejnym wydaniu $z$ końca 2016 r.

\section{PADALEC KOLCHIDZKI ANGUIS COLCHICA (NORDMANN, 1840)}

Do czasu upowszechnienia stosowania danych molekularnych $\mathrm{w}$ systematyce i taksonomii gadów, wyróżniano dwa gatunki padalców występujące w Europie - padalca peloponeskiego Anguis cephallonica (Werner, 1894), występującego niemal wyłącznie na Półwyspie Peloponeskim, oraz mocno zmiennego morfologicznie padalca zwyczajnego $A$. fragilis (Linnaeus, 1758), zasiedlajacego znaczna część Europy i zachodniej Azji. Badania genetyczne europejskich padalców przeprowadzone przez GvOŽDÍKA i współaut. (2010b) wykazały jednak, że poszczególne formy padalca zwyczajnego, niekiedy uznawane za podgatunki, cechuja się zaskakująco wysokim zróżnicowaniem genetycznym. Średni dystans genetyczny w mitochondrialnym DNA (mtDNA) pomiędzy różnymi formami padalców wynosił ok. $7 \%$, czyli niewiele mniej niż pomiędzy padalcami a żółtopuzikami (Pseudopus), ich najbliższymi krewnymi, klasyfikowanymi jednak w odrębnym rodzaju (GvožDík i współaut. 2010b). Co ważne, dywergencja $\mathrm{w}$ mtDNA zbiega się $\mathrm{z}$ różnicami $\mathrm{w}$ genomie jądrowym. $\mathrm{Z}$ tego powodu dawne podgatunki padalca zwyczajnego zostały podniesione do rangi odrębnych gatunków: padalec zwyczajny $A$. fragilis (sensu stricto), padalec kolchidzki A. colchica (Ryc. 1B), padalec grecki A. graeca (Bedriaga, 1881), a później również padalec włoski $A$. veronensis (Pollini, 1818) (GVOŽDík i współaut. 2010b,
2013). Rzecz jasna, miało to istotne implikacje nie tylko dla systematyki i taksonomii gadów, lecz również dla ochrony tych zwierząt. Doprowadziło też do wzrostu zainteresowania badaniami różnic morfologicznych i ekologicznych pomiędzy różnymi taksonami padalców.

Długo pozostawało niejasne, która forma (lub które formy) padalca występuje w Polsce. DELY (1972) opisał osobnika A. colchica z okolic Krakowa. JUSZCZYK (1987) stwierdził jednak jednoznacznie, że obszar Polski zasiedlaja wyłacznie padalce $z$ typowej formy fragilis. Późniejsze badania molekularne potwierdziły występowanie padalców kolchidzkich we wschodniej Polsce (GvožDÍK i współaut. 2010b, 2013). Dokładne rozmieszczenie obu gatunków w Polsce, a także kwestia, w jakim stopniu ich zasiegi na siebie nachodza, nie jest jeszcze ustalone. Wydaje się jednak, że padalec zwyczajny występuje przede wszystkim na zachodzie kraju, zaś padalec kolchidzki przede wszystkim na wschodzie, w czym zgadzają się zarówno badania morfologiczne, jak i molekularne (JABLONSKI i współaut. 2017, SKÓRZEWSKI 2017). W południowej części kraju padalec zwyczajny występuje na zachód od Wisły, zaś padalec kolchidzki po jej obu stronach, natomiast w północnej Polsce $A$. fragilis jest obecny po obu stronach Wisły, a $A$. colchica, tylko na wschód od niej (JABLONSKI i współaut. 2017, SkÓRZEWSKI 2017). Mimo iż większa część kraju zasiedlana jest przez padalca zwyczajnego, większą zmiennościa genetyczna cechuje się padalec kolchidzki (JABLONSKI i współaut. 2017).

Do rozróżniania poszczególnych gatunków padalców wykorzystywano przede wszystkim trzy cechy morfologiczne: ułożenie tarczek przedczołowych na grzbietowej stronie głowy, liczbę rzędów łusek wokół tułowia oraz widoczność otworu słuchowego (Sos 2010). U padalca zwyczajnego tarczki przedczołowe najczęściej szeroko się ze sobą stykaja, zaś $\mathrm{u}$ kolchidzkiego sa rozdzielone, jednak oba te typy, jak również stan pośredni (stykające się narożami), moga występować u obu gatunków (zob. ryc. 1. w SKÓRZEWSKI 2017). Liczba rzędów łusek wokół tułowia wynosi 24-26 u padalca zwyczajnego i 26-30 u kolchidzkiego, zaś otwór słuchowy jest niewidoczny u pierwszego $z$ tych gatunków, a widoczny u drugiego. Badania populacji padalca kolchidzkiego $z$ Rumunii sugeruja, że ostatnia $z$ tych cech jest najbardziej wiarygodna, ponieważ ponad 99\% osobników ma wyraźnie widoczny otwór słuchowy. Wydaje się jednak, że im bardziej na północ, tym cecha ta jest bardziej zmienna (Sos 2010); np. w Bieszczadach (skąd genetycznie potwierdzono jedynie A. colchica; JABLONSKI i 
współaut. 2017), blisko połowa padalców nie ma wyraźnie widocznych otworów słuchowych (BŁAżUK 2007). Tak więc nawet kombinacja powyższych trzech cech morfologicznych nie daje jednoznacznej odpowiedzi na pytanie, $z$ jakim padalcem mamy do czynienia. Identyfikację komplikuje też fakt występowania mieszańców, które morfologicznie sa prawdopodobnie formami pośrednimi między gatunkami rodzicielskimi (GVOŽDÍK i współaut. 2013, SzABÓ i VÖRÖS 2014). $\mathrm{Z}$ tego powodu, w Atlasie..., podobnie jak w przypadku rzekotek, występowanie tych gatunków zostało przedstawione na jednej mapie (SURA 2018a).

Obecnie padalec zwyczajny jest w Polsce gatunkiem częściowo chronionym, natomiast padalec kolchidzki, mimo wiedzy na temat jego występowania w kraju od 2010 r. (GVoŽDÍK i współaut. 2010b, 2013), nie podlega żadnej formie ochrony.

\section{BUFOTES VARIABILIS (PALLAS, 1769)}

W ostatnich latach systematyka ropuch z rodzaju Bufo (rodzina: ropuchowate Bufonidae) była przedmiotem wielu kontrowersji. Do najciekawszych przypadków można zaliczyć ropuchy zielone, skupione w podgrupie Bufo viridis, które cechuje unikatowy system rozrodu $z$ trzema poziomami ploidii. W zależności od położenia geograficznego spotkać możemy populacje di-, tri- lub nawet tetraploidalne, przy czym Europę zasiedlaja te pierwsze (STÖCK i współaut. 2006). W 2006 r. FROST i współaut. wydzielili je do rodzaju Pseudepidalea, jednak kilka lat później okazało się, że rodzaj ten jest młodszym synonimem rodzaju Bufotes (DuBoIs i BouR 2010). Chociaż początkowo sugerowano, by wszystkie eurazjatyckie ropuchy (w tym zielone) znów trafiły do rodzaju Bufo (DuBois i Bour 2010), to ostatecznie utrzymano odrębność rodzaju Bufotes (FROST 2013).

Wcześniej, bo już w 2006 r. zasugerowano, że niektóre taksony dotychczas uważane za podgatunki ropuchy zielonej maja na tyle różny mitochondrialny DNA, by nadać im status odrębnego gatunku. Stało się tak między innymi z Bufotes (wcześniej Bufo) variabilis (STÖCK i współaut. 2006) (Ryc. 1C). Gatunek ten, morfologicznie nieodróżnialny od B. viridis (Laurenti, 1768), występuje przede wszystkim w Grecji oraz dalej na wschód, przez Turcję, Cypr, aż po Syrię, Liban, Arabię Saudyjską czy Kazachstan (STÖCK i współaut. 2006, AvCI i współaut. 2015). Izolowane populacje tego gatunku występuja także w Europie, między innymi w północnych Niemczech, Danii czy Szwecji. Okazuje się również, że oba gatunki na nie- których obszarach moga występować sympatrycznie.

Wstępne badania przeprowadzone w Polsce wykazały, że $B$. variabilis wystepuje również na terenie kraju, jednak dane na temat rozmieszczenia tego gatunku są szczątkowe, a wyników jak dotąd nie opublikowano. Wiadomo jedynie, że mitochondrialne haplotypy charakterystyczne dla $B$. variabilis wykryto w okolicach Krakowa, Olkusza czy Suwałk (Iwko 2012, PROFUs i SuRA 2018, M. Pabijan inf. ust.) oraz że obie formy krzyżują się i wydaja płodne potomstwo.

Odrębność systematyczna $B$. variabilis jest jednak kwestionowana przez wiele autorytetów (Avci i współaut. 2015). Dopóki więc nie zostanie rozstrzygnięty status tego taksonu, nie można jednoznacznie stwierdzić, czy mamy do czynienia $z$ kolejnym gatunkiem ropuchy $\mathrm{w}$ Polsce, czy raczej podgatunkiem lub forma w obrębie $B$. viridis.

\section{ŻABA BAŁKAŃSKA PELOPHYLAX KURTMUELLERI (GAYDA, 1940)}

Badania profesora Leszka Bergera prowadzone w drugiej połowie XX w. wykazały, że żaby zielone (rodzina: żaby właściwe Ranidae) występujace $\mathrm{w}$ Polsce dziela się na trzy odrębne formy morfologiczne: żaby wodne Rana esculenta esculenta [obecnie Pelophylax esculentus (Linnaeus, 1758)], żaby jeziorkowe $R$. e. lessonae $[P$. lessonae (Camerano, 1882)] i żaby śmieszki $R$. ridibunda $[P$. ridibundus (Pallas, 1771)], które następnie podniósł do rangi gatunków (BERGER i MiCHAEOWSKI 1963). W kolejnych latach Berger przeprowadził szereg eksperymentalnych krzyżówek w warunkach hodowlanych pomiędzy żabami zielonymi, w wyniku których dowiódł, że żaba wodna nie jest gatunkiem o typowej, mendlowskiej segregacji chromosomów, lecz hybrydogenetycznym mieszańcem żaby jeziorkowej i żaby śmieszki, powstającym przede wszystkim na drodze krzyżówek wstecznych $z$ jednym $z$ gatunków rodzicielskich (BERGER 1969). Te przełomowe odkrycia doprowadzily do opisania wielu kolejnych taksonów, dzięki czemu wiemy, że zachodnią Palearktykę zamieszkuje przynajmniej 14 gatunków i trzy gatunki hybrydogenetyczne żab zielonych, a kolejne czekaja na opisanie (KolENDA i PABIJAN 2016).

W wyniku badań molekularnych prowadzonych w ostatnich latach dowiedziono, że w wielu krajach Europy Środkowej i Zachodniej, np. Belgii, Szwajcarii czy Włoszech, dokonano celowych introdukcji lub przypadkowych zawleczen nierodzimych gatunków żab zielonych (HoLSBEeK i współaut. 2008, DuBEY i współaut. 2014). W 2012 r. u żab śmieszek oraz żab wodnych 
pochodzacych $z$ Doliny Baryczy stwierdzono allele charakterystyczne dla żaby bałkańskiej P. kurtmuelleri (Gayda, 1940) (HAUSWALDT i współaut. 2012). Gatunek ten (Ryc. 1D), jak sama nazwa wskazuje, występuje przede wszystkim w południowej części Bałkanów i jest łudząco podobny do żaby śmieszki, od której można go odróżnić jedynie przy użyciu wybranych markerów genetycznych lub analizy wydawanych przez samce odgłosów (MARRACCI i współaut. 2011, HAUSWALDT i współaut. 2012, LUKANOV i współaut. 2015). Dalsze badania potwierdziły, że żaby zielone zamieszkujace Dolinę Baryczy maja w swoim genomie fragmenty charakterystyczne dla żab bałkańskich, a niektóre również mitochondrialny DNA typowy dla tego gatunku (KolENDA i współaut. 2017). Wykryty haplotyp mitochondrialnego DNA okazal sie identyczny $z$ tym, jaki maja żaby żyjące na pograniczu Albanii, Grecji i Macedonii. Prawdopodobnie więc region ten, znany przede wszystkim $z$ trzeciorzędowych jezior Ochrydzkiego i Prespy, jest źródłem żab bałkańskich stwierdzonych w Polsce. Przyczyny pojawienia się tego gatunku $\mathrm{w}$ naszym kraju sa niejasne, ale może wyjaśnić je jedna $z$ trzech hipotez (zgodnie $z$ KOLENDA $i$ współaut. 2017). Po pierwsze, mogło dojść do intencjonalnego wypuszczenia lub przypadkowej introdukcji żab bałkańskich podczas zarybiania Stawów Milickich rybami pochodzącymi $z$ Bałkanów, a następnie do ich krzyżowania się $z$ gatunkami pospolicie tu występujaccymi, przede wszystkim żaba wodna i żaba śmieszką. Druga hipoteza zakłada, że żaba bałkańska i żaba śmieszka sa gatunkami kryptycznymi, a prawdziwy zasięg występowania tej pierwszej rozciaga sie od południowych Bałkanów aż do Polski. Niewykluczone również, że żaba bałkańska może być niedawno oddzielona linia filogeograficzną w obrębie szeroko rozpowszechnionego i polimorficznego gatunku, jakim jest żaba śmieszka, o czym świadczy niewielkie zróżnicowanie pomiędzy tymi gatunkami (LYMBERAKIS i współaut. 2007, HOFMAN i współaut. 2016). Wart podkreślenia jest również fakt, że status systematyczny żaby bałkańskiej jest niepewny, a część naukowców przychyla się do wyżej wspomnianej hipotezy o niedawnym rozdziale obu taksonów (SIllero i współaut. 2014).

Dalsze badania obejmujace inne populacje żab zielonych w naszym kraju oraz wyjaśniające odrębność gatunkowa żaby bałkańskiej wydaja się konieczne. Obecnie w naszym kraju ma on status gatunku kryptogenicznego, to znaczy w tym momencie nie jest możliwe jednoznacznie określenie, czy gatunek ten jest rodzimy, czy obcy (IOP 2018).

\section{MURÓWKA ZWYCZAJNA PODARCIS MURALIS (LAURENTI, 1768)}

Murówka zwyczajna Podarcis muralis, czasem zwana po prostu jaszczurka murowa, to gatunek niewielkiej jaszczurki należący do rodziny jaszczurkowatych Lacertidae (Ryc. 1E). Jego przedstawiciele cechuja się nieco spłaszczonym grzbietobrzusznie ciałem. Ubarwienie jest zmienne, zwykle w różnych odcieniach brązów i szarości, często $z$ pasami i licznymi niewielkimi plamami (SPEYBROECK i współaut. 2016). Murówki można pomylić $z$ nieco podobnymi morfologicznie jaszczurkami żyworodnymi (JABLONSKI i wspólaut. 2018), jednak zajmuja one zdecydowanie inne siedliska - sa ciepłolubne i często występują na skałach, po których umieja się dobrze wspinać.

Murówka zwyczajna jest jedna $z$ najszerzej rozprzestrzenionych i najliczniejszych jaszczurek Europy. Zasięg jej występowania obejmuje tereny od Hiszpanii na zachodzie po Bułgarię i Turcje na wschodzie. Południowa granica zasięgu biegnie wzdłuż brzegu Morza Śródziemnego od Pirenejów po północno-zachodnia Turcję. Granica północna jest jednak trudniejsza do wyznaczenia. Jaszczurki te występuja w niemal całej Francji, południowo-zachodnich Niemczech, Austrii, Czechach, Słowacji, Węgrzech i Rumunii (BöHME i współaut. 2009). Nawet na północ od zwartego zasięgu występowania warunki klimatyczne sprzyjaja tym jaszczurkom, a ponieważ murówki często były przedmiotem introdukcji, znane sa liczne stanowiska tego gatunku za północna granica zwartego zasięgu (WiRga i MAJTYKa 2015a).

W 2011 r. po raz pierwszy zaobserwowano murówki $\mathrm{w}$ nieczynnych częściach kamieniołomów w Strzelinie i Przewornie (województwo dolnośląskie). Ponad dwuletnie obserwacje potwierdzily występowanie tam rozmnażających się stabilnych populacji. Najbliższe stanowisko tego gatunku znajduje się ok. $135 \mathrm{~km}$ (w linii prostej) na południe, w Kraju Morawsko-Śląskim (Czechy), dlatego też stwierdzono, że murówka jest prawdopodobnie gatunkiem obcym w Polsce (WIRGA i MAJTYKA 2013, 2015b; SURA 2018b). Spekulowano, że osobniki tego gatunku mogły się tam dostać pociagami towarowymi przywożącymi i wywożacymi urobek $z$ kamieniołomów (DUDEK 2014). Jest to niewykluczone, ponieważ $z$ innych miejsc w Europie donoszono już o przypadkach transportu tych jaszczurek koleja (SANTOS i współaut. 2019). Mniej znany jest fakt, że murówki $z$ terenów dzisiejszej Polski opisywano już blisko 90 lat wcześniej. Węgierski zoolog, baron Fejerváry, opisał kilka osobników tego gatunku na podstawie okazów $\mathrm{z}$ muzeum $\mathrm{w}$ Budapesz- 
cie, schwytanych przez Alexandra Pongrácza (FEJERVÁRY 1923). Pochodziły one jakoby $z$ Kielc, Sosnowca (z Maczek), Trzebini, Buska i Puław. Fejerváry był cenionym herpetologiem i zajmował się m.in. anatomia murówek, zapewne więc poprawnie zidentyfikował okazy. Niewykluczone jednak, że badane przez niego jaszczurki miały błędnie opisane miejsce pochodzenia (FUDAKOWSKI 1958). Również PAX $(1921,1925)$ wspominał, że na Śląsku wypuszczono murówki, jednak nie podał dokładnego miejsca. Od tego czasu, aż do obserwacji WIRGI i MAJTYKI (2013), ani na Śląsku, ani nigdzie w Polsce nie dokonano jednoznacznego stwierdzenia tego gatunku.

Pouczajace może być poznanie statusu najbliżej położonych populacji murówek. W Czechach występuja trzy populacje tych jaszczurek, wszystkie izolowane, stad też często uznawano je za introdukowane (np. WIRGA i MAJTYKA 2013, SURA 2018b). Niespodziewanie jednak badania genetyczne wskazują, że są one najbliżej spokrewnione $z$ rodzimymi populacjami murówek ze Słowacji. Ponadto, u dwóch $z$ nich występuja niespotykane nigdzie indziej haplotypy, co sugeruje, że moga one być reliktami, a nie wynikiem introdukcji (JABLONSKI i współaut. 2018). Populacje te występuja niedaleko Bramy Morawskiej, przesmyku między Sudetami a Karpatami, czyli miejsca, przez które wiele organizmów przedostało się $z$ południa do Polski po ostatnim zlodowaceniu. Planowane badania genetyczne moga ostatecznie wyjaśnić status polskich populacji murówek. Obecnie gatunek ten nie podlega ochronie prawnej $\mathrm{w}$ Polsce, a przez IOP PAN murówka jest uznawana za gatunek obcy (IOP 2018).

\section{ZASKRONIEC RYBOŁÓW NATRIX TESSELLATA (LAURENTI, 1768)}

Zaskroniec rybołów to gatunek węża należący do rodziny połozowatych Colubridae. Ubarwienie grzbietowej strony ciała jest zmienne, zazwyczaj oliwkowe lub oliwkowo-brazowe, pokryte ciemniejszymi plamami (Ryc. 1F). Wąż ten dorasta do $150 \mathrm{~cm}$, przy czym samce sa mniejsze od samic i zazwyczaj nie przekraczaja $1 \mathrm{~m}$ długości ciała. Zaskroniec rybołów związany jest ze środowiskiem wodnym, gdzie odżywia się głównie niewielkimi rybami i płazami. Żyje przy małych strumieniach, ciekach czy zbiornikach wodnych. Swoim wyglądem przypomina nieco zaskrońca zwyczajnego $N$. natrix. Odróżnia go: brak plam skroniowych (rzadko moga pojawiać się jedynie u młodocianych osobników), liczba tarczek przedocznych (u zaskrońca zwyczajnego jedna, u zaskrońca rybołowa dwie-trzy) oraz ubarwienie ciała u zaskrońca zwyczajnego jest ono zazwyczaj ciemniejsze i w odcieniach szarości (SPEYBROECK i współaut. 2016).

Gatunek ten występuje od Szwajcarii i Włoch w Europie Środkowej, aż po Chiny na wschodzie oraz po północny Egipt na południu i południowa Rosję oraz Kazachstan na północy (AGASYAN i współaut. 2010).

Pierwszej i jak dotąd jedynej obserwacji zaskrońca rybołowa w Polsce dokonano w lipcu 2009 r. (VLČEK i współaut. 2010). Był to młodociany osobnik znaleziony po polskiej stronie rzeki Olzy, między miejscowościami Kaczyce Górne i Brzezówka. Jak dotąd nie ustalono, czy zaobserwowany osobnik był migrantem $z$ czeskiej populacji czy został on intencjonalnie lub przypadkowo przesiedlony. Najbliższe znane stanowisko tego gatunku znajduje się $9,5 \mathrm{~km}$ na południowy zachód, niedaleko miejscowości Havírov w Czechach. Jest to izolowana populacja usytuowana ok. $150 \mathrm{~km}$ na północ od jego zwartego zasięgu występowania (VLČEK i współaut. 2010). Obserwacji z 2009 r. nie potwierdzono jednak do dziś, chociaż w latach 2011-2013 różni herpetolodzy penetrowali teren nad Olza (VLČEK i współaut. 2011, KOLANEK 2013, SURA 2018c).

Co ciekawe, już w 1923 r. FEJERVÁRY podał, że w prywatnej kolekcji węgierskiego przyrodnika Alexandra Pongrácza znajduje się $N$. tessellata (nie wiadomo ile osobników) z Ludyni (woj. świętokrzyskie). Były również inne doniesienia o obecności tego gatunku w Polsce (na Babiej Górze), jednak wszystkie uznano za niewiarygodne (FUDAKOWSKI 1958).

Mimo pojedynczej obserwacji osobnika o niepewnym pochodzeniu, zaskroniec rybołów od 2014 r. podlega ścisłej ochronie gatunkowej (ROZPORZĄDZENIE 2014, 2016).

\section{ŻÓŁW OZDOBNY TRACHEMYS SCRIPTA}

(THUNBERG IN SCHOEPFF, 1792)

Żółw ozdobny Trachemys scripta (Thunberg in Schoepff, 1792) pierwotnie zasiedlał południowo-wschodnią część Stanów Zjednoczonych. Za sprawa masowego importu jako zwierzecia domowego oraz licznym introdukcjom obecnie występuje w ponad 70 krajach i zaliczany jest do 100 najbardziej inwazyjnych gatunków zwierząt w skali globalnej (DAISIE 2008). Po wprowadzeniu ograniczeń w imporcie na teren Unii Europejskiej najpospolitszego podgatunku - żółwia żółtobrzuchego T. s. scripta - do kraju zaczęto masowo sprowadzać także pozostałe dwa podgatunki: żółwia czerwonolicego T. s. elegans (Wied, 1839) i żółwia żółtolicego T. s. troostii (Holbrook, 1836) (KITOWSKI i PA- 
CHOL 2009, KITOWSKI 2013). Niestety żółwie te szybko stawały się zbyt duże i uciażliwe dla nabywców. Początkowo wiele niechcianych żółwi ozdobnych trafiało do ogrodów zoologicznych, gdzie w 2005 r. utrzymywano ponad 700 osobników (średnio 56,3 osobnika na placówkę) (ŚwIĘTEK i współaut. 2015), jednak obecnie w wielu ogrodach zaprzestano przyjmować porzucone zwierzęta. Jednocześnie wiele osobników było wypuszczanych do środowiska lub uciekały $z$ niedostatecznie zabezpieczonych przydomowych oczek wodnych. Obecnie lokalnie prowadzi się odłowy żółwi w otwartych akwenach; w samym tylko woj. lubelskim w latach 20152017 odłowiono 134 osobniki (B. Gorzkowski - http://fundacja-epicrates.pl/ inf. ustna.).

Obecnie wszystkie trzy formy wykryto w środowisku, szczególnie w pobliżu dużych miast, ale także na terenach chronionych (KALA i współaut. 2015, NAJBAR i SURA 2018, WILCZEK i współaut. 2018). Ponadto, pojawiają się doniesienia o odłowach ze środowiska innych gatunków żółwi wodno-błotnych, w tym żółwia malowanego Chrysemys picta (Schneider, 1783), żółwia ostrogrzbietego Graptemys pseudogeographica (Gray, 1831), rzadziej skorpuchy jaszczurowatej Chelydra serpentina (Linnaeus, 1758), żółwiaka kolcowatego Apalone spinifera (LeSueur, 1827), żółwia chińskiego Mauremys reevesii (Gray, 1831) i żółwia $z$ gatunku Pseudemys concinna (LeConte, 1830) (KALA i współaut. 2015). Podstawowe cechy morfologiczne pozwalające odróżnić krajowego żółwia błotnego Emys orbicularis (Linnaeus, 1758) od gatunków obcych prezentuja KALA i współaut. (2015, zobacz tabela 1, s. 5051).

Obecność obcych i inwazyjnych gatunków żółwi w środowisku wpływa negatywnie na rodzima przyrodę, nawet jeśli sa to populacje nierozmnażajace się, gdyż wyrośnięte osobniki zazwyczaj nie maja wrogów naturalnych (POLO-CAVIA i współaut. 2011). Trudno jednak określić całkowity zakres ich szkodliwości (IoP 2018). O ile w przypadku żółwi ozdobnych doświadczenia europejskie opisujace negatywny wpływ na rodzime gatunki, jak i ekosystemy, sa dość dobrze udokumentowane, to $\mathrm{w}$ przypadku pozostałych taksonów nadal brakuje informacji (DAISIE 2008). Żółwie wodno-błotne sa generalistami pokarmowymi wpływajacymi na gatunki rodzime bezpośrednio poprzez drapieżnictwo i konkurencję o zasoby (KALA i współaut. 2015). Mogą stanowić zagrożenie epidemiologiczne (wektory chorób czy nosiciele pasożytów) (Mitura i współaut. 2017, DEMKOWSKA-KUTRZEPA i współaut. 2018), jak i znaczaco zmieniać ekosystem, np. nisz- czac makrofity w zbiornikach, przekształcajac sieci troficzne (efekty kaskadowe).

Dotychczas nie stwierdzono udanych przypadków rozrodu obcych gatunków żółwi na terytorium Polski, jednocześnie wdrożenie przygotowanego Programu postepowania $z$ inwazyjnymi gatunkami żółwi na terenie Polski (KALA i współaut. 2015) skutkować powinno stopniowym zanikaniem ich stanowisk. Niemniej w przypadku zwierzat długowiecznych, jakimi sa żółwie, nawet podjęcie skutecznych i stanowczych działań zapobiegających inwazji nie wyeliminuje ich w pełni ze środowiska, a przypadki wykrycia kolejnych osobników będa się powtarzać. Jako element obcy w faunie krajowej, żółwie te nie podlegaja ochronie gatunkowej, a odłowione osobniki powinny trafiać do wyspecjalizowanych ośrodków i hodowli zamkniętych.

\section{INNE GATUNKI OBCE}

Obok powszechnie już niemal występujacych w Polsce żółwi ozdobnych, coraz częściej pojawiają się doniesienia o innych obcych gatunkach płazów i gadów stwierdzonych w środowisku (Iop 2018). Sa to jednak pojedyncze przypadki, które dotycza albo osobników, które zostały celowo wypuszczone przez znudzonych nimi hodowców, albo uciekinierów $z$ hodowli lub tzw. pasażerów na gapę, którzy dostali się do naszego kraju np. $z$ transportem warzyw i owoców. Najczęściej trafiaja się więc m.in. inne gatunki żółwi wodno-lądowych, o zbliżonej biologii do żółwi ozdobnych, żółwie stepowe lub greckie oraz popularne w hodowlach dusiciele należace do rodzin Boidae i Pythonidae czy połozowate Colubridae (IoP 2018). Należy podkreślić, że warunki klimatyczne panujace w naszym kraju sa jednak niesprzyjajace dla większości egzotycznych gadów i płazów, które najczęściej gina podczas pierwszych przymrozków. Wykaz gatunków obcych stwierdzonych na terytorium Polski prowadzi Instytut Ochrony Przyrody PAN w Krakowie (IoP 2018). Obecnie znajduje się w nim 29 taksonów gadów i dwa płazów. Ciekawostka może być figurowanie tu pętówki babienicy Alytes obstetricans (Laurenti, 1768), która w 1894 r. nieskutecznie próbowano introdukować w okolicach góry Ślęży (UDZIElA i współaut. 1910, PAX 1921). Ponadto stwierdzono jednego, prawdopodobnie introdukowanego, osobnika w kamieniołomie w Strzegomiu (PAX 1921, 1925). Obecnie pętówka uznawana jest zarówno za gatunek wymarły, jak i obcy na terytorium kraju (IOP 2018). 


\section{PERSPEKTYWY}

Zaprezentowany stan wiedzy dotyczący występowania płazów i gadów w Polsce wskazuje dalsze możliwe kierunki badań herpetologicznych. Szczególnie dla par gatunków kryptycznych (poza ustaleniem ich rzeczywistego rozmieszczenia) kluczowe wydaje się rozpoznanie cech niemorfologicznych, takich jak różnice w ekologii, zachowaniu, cytogenetyce lub biochemii. Nadal brakuje wiedzy w zakresie barier reprodukcyjnych i przepływu genów pomiędzy nimi, co ma znaczenie w ekologii ewolucyjnej oraz genetyce konserwatorskiej gatunków. Rzutuje to również na możliwości oznaczenia gatunku w terenie, co ma bezpośredni wpływ na ochronę populacji mieszańcowych.

$Z$ punktu widzenia prowadzenia trwałej ochrony przyrody na szczeblu krajowym, olbrzymie znaczenie ma nie tylko rozpoznanie poszczególnych gatunków, ale również relacji pomiędzy poszczególnymi liniami filogenetycznymi czy podgatunkami. W ten sposób definiowane ewolucyjnie odrębne jednostki ( $z$ ang. evolutionarily significant units) reprezentuja genetycznie zróżnicowane grupy osadzone w przestrzeni, nawet jeśli nie maja odrębnej pozycji taksonomicznej (MoRITZ 1994). DUFRESNES (2018), opierając się na licznych wcześniejszych pracach, podkreśla ich znaczenie w zrozumieniu wzorców różnorodności gatunkowej płazów zachodniej Palearktyki. Niestety wcią̇̇ bagatelizowana jest kwestia trwałości genetycznej odmiennych populacji zasiedlajacych obszar Polski, a tego typu dane nie sa brane pod uwage w ramach zarządzania poszczególnymi gatunkami (zobacz RozPORZĄDZENIE 2016, GŁOWACIŃSKI i SURA 2018). Tymczasem jest ona kluczem do zachowania różnorodności genetycznej i gatunkowej, a tym samym długotrwałej i efektywnej ochrony przyrody, tym bardziej, że dla niektórych gatunków posiadamy już tego typu dane (np. PABIJAN i współaut. 2005, PABIJAN i BABIK 2006). Dopiero na tej podstawie należałoby zaktualizować status ochrony poszczególnych gatunków występujacych w Polsce.

Zgodnie $z$ przedstawionym stanem badań dotyczącym rozmieszczenia płazów i gadów w Polsce, konieczne jest pilne uaktualnienie listy gatunków chronionych, wymienionych w ROZPORZĄDZENIU z 2016 r. (Tabela 1). Kluczowym jest uzupełnienie listy o rzekotkę wschodnia i padalca kolchidzkiego ze względu na ich rozległy zasięg i naturalny charakter występowania na terenie Polski. Obecnie dla obu gatunków nie maja zastosowania najważniejsze zapisy ustawy, zabraniające chwytania, zabijania i prześladowania, jak i zakaz niszczenia ich miejsc rozro- du (Dz.U. 2004 nr 92 poz. 880 z późń. zm.). Ta luka prawna może się okazać bardzo korzystna dla inwestorów i zarządców terenów; w świetle prawa nie muszą się oni przejmować gatunkami, które nie sa objęte ochrona prawna. Stwierdzenie, że na ochronie np. rzekotki drzewnej korzysta rzekotka wschodnia, chociaż w teorii możliwe, nie jest zatem w pełni uprawnione (PROFUs i MAJTYKA 2018). Dla rzekotki wschodniej sugerujemy więc przyjeccie analogicznego statusu jak dla rzekotki drzewnej, tj. ochrony ścisłej wraz z wprowadzeniem nakazu ochrony czynnej (RozPORZADZENIE 2016). Podobnie zasadne jest nadanie statusu ochrony częściowej padalcowi kolchidzkiemu, tak jak w przypadku padalca zwyczajnego (ROzPORZĄDZENIE 2016), proponowane także przez SKóRZEWSKIEGO (2017) i JABLONSKIEGO i współaut. (2017). Objęcie ochrona obu gatunków postulowano w trakcie konsultacji społecznych odbywających się przed wprowadzeniem aktualnego RozPORZĄDZENIA (2016), jednak $z$ niezrozumiałych względów Ministerstwo Środowiska pozostawiło ten wniosek bez odpowiedzi (RAPORT 2016). Jednocześnie, w zwiąku $z$ niepełnie rozpoznanym rozmieszczeniem zarówno padalców, jak i rzekotek, konieczne jest przeprowadzenie szczegółowych badań terenowych i laboratoryjnych w celu jednoznacznego wyznaczenia zasięgów występowania poszczególnych gatunków i rozmieszczenia stref ich hybrydyzacji. Do czasu aktualizacji obowiazującego ROZPORZĄDZENIA (2016) tymczasowym rozwiąaniem może być wprowadzenie rzekotki wschodniej i padalca kolchidzkiego na wojewódzkie listy gatunków chronionych (patrz art. 53 ustawy z 16 kwietnia 2004 r. o ochronie przyrody). W przypadku żaby bałkańskiej, ropuchy $B$. variabilis oraz jaszczurki murowej zasadne wydaje się pozostawienie ich poza lista gatunków chronionych, przynajmniej do czasu rozstrzygnięcia ich statusu. Objęcie ochrona ścisła zaskrońca rybołowa na podstawie obserwacji pojedynczego osobnika o niepewnym pochodzeniu budzi uzasadnione watpliwości, w związku $z$ czym sugerowane jest usunięcie go $z$ listy gatunków chronionych, choć konieczne są dalsze badania nad jego występowaniem na pograniczu polsko-czeskim.

Odrębnym zagadnieniem jest bieżące aktualizowanie listy gatunków obcych i inwazyjnych, co do których istnieje duże zagrożenie przedostania się $z$ warunków wiwaryjnych do środowiska, lub tych, które sa coraz częściej odławiane interwencyjnie przez właściwe służby. Listę tego typu zdarzeń od niedawna prowadzi Iop (2018). Co ważne, dopóki na terenie kraju nie powstanie sieć azyli i schronisk dla niechcianych zwie- 
rzat egzotycznych, będa one nadal trafiały do środowiska (KALA i współaut. 2015) lub ogrodów zoologicznych (ŚWIETEK i współaut. 2015). Kluczowym jest monitoring i konsekwentne wdrażanie środków zaradczych przeciwko gatunkom inwazyjnym, jak np. Program... (KALA i współaut. 2015) wraz z szeroko rozumianą edukacją. Żółwie ozdobne stanowia również dobra grupę modelową do wdrażania procedur obejmujących inne gatunki obce (KALA i współaut. 2015). Należy mieć świadomość mechanizmów rynkowych, tj. sprowadzania przez importerów nowych gatunków jako odpowiedzi na wprowadzane ograniczenia w obrocie (KITOWSKI 2013). Zmusza to do stałego monitoringu i szybkiego reagowania $\mathrm{w}$ przypadku wykrycia nieprawidłowości i masowego importu nowych gatunków. Dobrym przykładem działań monitorujacych handel sa np. badania KITOWSKIEGO (2013), dotyczące obrotu żółwiami ozdobnymi, czy KACZMARSKIEGO i KOLENDY (2018), dotyczace obrotu płazami egzotycznymi w Internecie.

Warto zauważyć, że niektóre gatunki, których współczesne występowanie w Polsce jest kontrowersyjne lub watpliwe, maja dobrze udokumentowany zapis kopalny $z$ terenów dzisiejszej Polski. I tak np. murówka zwyczajna czy zaskroniec rybołów znane sa $z$ kilku stanowisk $z$ plejstocenu i czwartorzędu (np. MŁYNARsKI i współaut. 1984, IVANOV 2007). Niestety, ze względu na niekompletność materiału i ograniczoną wiedzę na temat osteologii współczesnych zwierzat, dokładne przypisanie okazu do gatunku jest często niemożliwe. Mimo tego nie budzi watpliwości fakt, że dawniej na terenach Polski żyły gatunki obecnie często uważane za nierodzime. Zgodnie $z$ definicja przyjęta przez IOP (2018), gatunków występujacych $\mathrm{w}$ Polsce $\mathrm{w}$ czasach prehistorycznych nie powinno się włączać do listy rodzimej fauny. Granica ta jest czysto arbitralna, jednak ma podstawy merytoryczne. Oczywiście, jeśli potwierdzone zostana reliktowość lub naturalny charakter ekspansji danego gatunku, powinien on być uznawany za rodzimy.

\section{PODSUMOWANIE}

Analizujac dotychczasowe dane dotyczace „nowych" gatunków w polskiej herpetofaunie należy przyjąć, że:

1) dwa (rzekotka wschodnia i padalec kolchidzki) sa gatunkami rodzimymi, a status czterech kolejnych (żaba bałkańska, ropucha B. variabilis, murówka zwyczajna, zaskroniec rybołów) jest niepewny i wymaga dalszych badań;
2) należy pilnie zaktualizować listę gatunków chronionych wymienionych w ROZPORZAQDZENIU 2016;

3) zasadnym wydaje się wprowadzenie regionalnego szczebla statusów ochronnych i prowadzenia lokalnych list gatunkowych $z$ uwzględnianiem najnowszej wiedzy $\mathrm{z}$ zakresu rozmieszczenia gatunków i ich form wyodrębnionych dzięki narzędziom molekularnym.

\section{PODZIEKOWANIA}

Danielowi Jablonskiemu, Janowi Kaczmarkowi i Natalii Kuśmierek dziękujemy za udostępnienie zdjęć, a Maciejowi Pabijanowi, Januszowi Kloskowskiemu oraz anonimowemu recenzentowi za cenne uwagi do manuskryptu.

\section{Streszczenie}

W ostatnich latach doszło do aktualizacji wiedzy o gatunkach płazów i gadów występujacych na terenie Polski. Okazało się, że dla części z nich brak jest w pełni jednoznacznych danych dotyczacych ich rozmieszczenia, pochodzenia czy także statusu taksonomicznego. W niniejszej pracy podsumowujemy obecny stan wiedzy na temat "nowych" gatunków oraz przedstawiamy propozycję zmian na liście gatunków chronionych. Rzekotka wschodnia i padalec kolchidzki sa gatunkami rodzimymi i powinny zostać objęte odpowiednio ochroną ścisła i częściową. Do czasu zaktualizowania stosownego Rozporządzenia sugerujemy wprowadzenie tych gatunków na wojewódzkie listy gatunków chronionych. Status dalszych czterech (żaby bałkańskiej, ropuchy B. variabilis, murówki zwyczajnej oraz zaskrońca rybołowa) jest niepewny i wymaga dalszych badań. Do czasu wyjaśnienia statusu zaskrońca rybołowa powinien on zostać usunięty $z$ listy gatunków chronionych.

\section{LITERATURA}

AgASYAN A., AVCI A., TUNIYEV B., IsAILOVIC J C., LYMBERAKIS P., ANDRÉN C., COGALNICEANU D., WILKINSON J., ANANJEVA N., ÜZÜM N., ORLOV N., PODLOUCKY R., TUNIYEV S., KAYA U., AJTIC R., VOGRIN M., CORTI C., MElladO V. P., SÁ-SOUSA P., CHEYlaN M., PleguezUELOS J., BAHA EL DIN S. M., NETTMANN H. K., DE HAAN C. C., STERIJOVSKI B., SCHMIDT B., MEYER A., 2010. Natrix tessellata. IUCN Red List of Threatened Species 2010, e. T157256A5062170.

AraúJo M. B., THUiller W., PEARson R. G., 2006. Climate warming and the decline of amphibians and reptiles in Europe. J. Biogeogr. 33, 1712-1728.

Avei A., TuniYeV B., CRNOBRnJA ISAIlOVIC J., LYMBERAKIS P., ANDRÉN C., COGALNICEANU D., WILKINSON J., ANANJEVA N., ÜZÜM N., ORLOV N., PODLOUCKY R., TUNIYEV S., KAYA U., Nilson G., SHARIFI M., PAPENFUss T., SHAFIEI BAFTI S., 2015. Bufotes variabilis. IUCN Red List of Threatened Species 2015, e. T153571A74506381.

BERGER L. 1969. Systematyka żab zielonych. Przegl. Zool. 13, 219-238.

BERGER L., MichaŁOWSKI J., 1963. Klucze do oznaczania kregowców Polski, cz. II, Płazy Amphibia. Wydawnictwo Naukowe PWN, Warszawa-Kraków. 
BŁAŻUK J., 2007. Herpetofauna doliny Sanu pod Otrytem $i$ terenów przyległych (Bieszczady $\mathrm{Za}$ chodnie). Gady. Rocz. Bieszcz. 15, 181-229.

Böhme W., PÉrez-Mellado V., Cheylan M., NetTMANN H. K., KRECSÁK L., STERIJOVSKI B., SCHMIDT B., LYMBERAKIS P., PODLOUCKY R., SINDACO R., AVCI A., 2009. Podarcis muralis. IUCN Red List of Threatened Species 2009, e.T61550A12514105.

DAISIE, 2008. DAISIE European Invasive Alien Species Gateway. http://www.europe-aliens. org/.

Dely O. G., 1972. Adatok a Kárpát-medencei törékeny gyík (Anguis fragilis Linnaeus) rendszertanához és elterjedéséhez [Beiträge zur Verbreitung und Systematik der Blindschleiche (Anguis fragilis Linnaeus) im Karpatenbecken]. Vertebr. Hungarica 13, 39-79.

DEMKOWSKA-KuTRZEPA M., STUDZIŃSKA M., ROCZEŃ-KARCZMARZ M., TOMCZUK K., ABBAS Z., RÓŻAŃSKI P., 2018. A review of the helminths co-introduced with Trachemys scripta elegans - a threat to European native turtle health. Amphibia-Reptilia 39, 177-189.

Dubey S., LEUENBERGER J., PerRin N., 2014. Multiple origins of invasive and 'native' water frogs (Pelophylax spp.) in Switzerland. Biol. J. Linn. Soc. 112, 442-449.

Dubey S., Lavanchy G., Thiébaud J., Dufresnes C., 2019. Herps without borders: a new newt case and a review of transalpine alien introductions in western Europe. Amphibia-Reptilia. $40,13-27$.

DUBOIS A., BOUR R, 2010. The nomenclatural status of the nomina of amphibians and reptiles created by Garsault (1764), with a parsimonious solution to an old nomenclatural problem regarding the genus Bufo (Amphibia, Anura), comments on the taxonomy of this genus, and comments on some nomina created by Laurenti (1768). Zootaxa 2447, 1-52.

DUDEK K., 2014. Railroads as anthropogenic dispersal corridors. Possible way of the colonization of Poland by a common wall lizard (Podarcis muralis, Lacertidae). Ecol. Quest. 20, 71-73.

DUFRESNES C., 2018 Patterns of amphibian diversity in the Western Palearctic. Herpetol. Bull. 145, 28-30.

Dufresnes C., MAJTYKA T., Baird S. J. E., GerCHEN J. F., BORZÉE A., SAVARY R., OGIElSKA M., PERRIN N., STÖCK M., 2016. Empirical evidence for large X-effects in animals with undifferentiated sex chromosomes. Sci. Rep. 6, 21029.

FEJERVÁRY G. J., 1923. Über die von Dr. A. Pongrácz in Polen gesammelten Amphibien und Reptilien. Arch. Naturgesch. 89, 1-35.

FORMICKI G., GUZIK M., ZAMACHOWSKI W., 2014. Płazy (Amphibia). [W:] Fauna Polski. Charakterystyka $i$ wykaz gatunków. BoGDANOWICZ W., CHUDZICKA E., PILIPIUK I., SKIBIŃSKA E. (red.). Muzeum i Instytut Zoologii PAN, Warszawa, $165-214$.

FROST D. R., 2013. Amphibian species of the world: an online reference. Version 5.6 (9 January 2013). American Museum of Natural History, Nowy Jork. http://research.amnh. org/herpetology/amphibia/index.html.

Frost D. R., GRANT T., FAIVOVICH J., BAIN R. H., HaAs A., Haddad C. F. B., De Sá R. A., ChanNing A., Wilkinson M., DonNEllan S. C., RaXworthy C. J., CAmpbell J. A., Blotto B. L., Moler P., DRewes R. C., Nussbaum R. A., LYNCH J. D., GREen D. M., WheEler W. C.,
2006. The amphibian tree of life. Bull. Am. Mus. Nat. Hist. 297, 1-370.

FUDAKOWSKI J., 1958. Remarks on the herpetological fauna of Poland. Acta Zool. Cracov. 2, 825-844.

GIERLIŃSKI G., GRABOWSKA J., GRABOWSKI M., JASKUŁA R., 2015. Ilustrowana encyklopedia płazów i gadów Polski. Fenix, Warszawa.

GŁowAciński Z., SuRA P., 2018. Atlas płazów $i$ gadów Polski. Status, rozmieszczenie, ochrona. PWN, Warszawa.

GVožDíK V., MORAVEC J., KLÜTSCH C., KotLíK P., 2010a. Phylogeography of the Middle Eastern tree frogs (Hyla, Hylidae, Amphibia) as inferred from nuclear and mitochondrial DNA variation, with a description of a new species. Mol. Phylogenet. Evol. 55, 1146-1166.

GVOŽDÍK V., JANDZIK D., LYMBERAKIS P., JABLONSKI D., MORAVEC J., 2010b. Slow worm, Anguis fragilis (Reptilia: Anguidae) as a species complex: genetic structure reveals deep divergences. Mol. Phylogenet. Evol. 55, 460-472.

GVOŽDÍK V., BENKOVSKÝ N., CROTTINI A., BELLATI A., Moravec J., Romano A., SACCHI R., JANDZIK D., 2013. An ancient lineage of slow worms, genus Anguis (Squamata: Anguidae), survived in the Italian Peninsula. Mol. Phylogenet. Evol. 69, 1077-1092.

Hauswaldt J. S., HÖER M., OGIElska M., ChrisTIANSEN D. G., DZIEWULSKA-SZWAJKOWSKA D., CZERNICKA E., VENCES M., 2012. A simplified molecular method for distinguishing among species and ploidy levels in European water frogs (Pelophylax). Mol. Ecol. Res. 12, 797805.

HOFMAN S., PABIJAN M., OsIKOWSKI A., LITVINCHUK S. N., SZYMURA J. M. 2016. Phylogenetic relationships among four new complete mitogenome sequences of Pelophylax (Amphibia: Anura) from the Balkans and Cyprus. Mitochondrial DNA 27, 3434-3437.

Holsbeek G., Mergeay J., Hotz H., Plotner J., VolcKAeRT F. A. M., DEMEESTER L., 2008. A cryptic invasion within an invasion and widespread introgression in the European water frog complex: the toll of uncontrolled commercial trade and weak international legislation. Mol. Ecol. 17, 5023-5035.

IoP, 2018. Gatunki obce $w$ Polsce. Instytut Ochrony Przyrody PAN, Kraków.

IVANOV M., 2007. Herpetological assemblages from the Pliocene to middle Pleistocene in Central Europe: palaeoecological significance. Geodiversitas 29, 297-320.

IwKo P., 2012. Subspecies or cryptic species complex - Bufotes viridis subgroup. [W:] Abstract book. I Studencka Konferencja Herpetologiczna, Wrockaw, 8-9 grudnia 2012. Studenckie Koło Naukowe Herpetologów, Wrocław, 16-17.

JABLONSKI D., NAJBAR B., GROCHOWALSKA R., GVOŽDÍK V., STRZALA T., 2017. Phylogeography and postglacial colonization of Central Europe by Anguis fragilis and Anguis colchica. Amphibia-Reptilia 38, 562-569.

JABLONSKI D., GVOŽDÍK V., CHOLEVA L., JANDZIK D., MORAVEC J., MAČÁT Z., VESELÝ M., 2018. Tracing the maternal origin of the common wall lizard (Podarcis muralis) on the northern range margin in Central Europe. Mitochondrion. doi: 10.1016/j.mito.2018.04.006.

JuszCZYK W., 1987. Płazy i gady krajowe. Część 3. Gady. PWN, Warszawa.

KACZMARSKI M., KOLENDA K., 2018. Non-native amphibian pet trade via Internet in Poland. Eur. J. Ecol. 4, 30-40. 
Kala B., KePEl A., SOlarz W., Wieckowska M., 2015. Program postepowania $z$ inwazyjnymi gatunkami żółwi na terenie Polski. Polskie Towarzystwo Ochrony Przyrody, Poznań.

KITOWSKI I., 2013. Examinations of the ember of invasive species problems: Trade turnover of cumberland sliders Trachemys scripta troostii in the pet shops of Eastern Poland. Int. J. Pure Appl. Sci. Technol. 15, 14-19.

KITOWSKI I., PACHOL D., 2009. Monitoring the trade turnover of red-eared terrapins (Trachemys scripta elegans) in pet shops of the Lublin Region, East Poland. North-West. J. Zool. $5,34-39$.

KOLANEK A., 2013. 18-22 sierpnia: obóz naukowy $w$ Cieszynie. Studenckie Koło Naukowe Herpetologów UWr, Wrocław. https://sites.google. com/site/herpetolodzy/aktualnosci/2013

KOlENDA K., PABIJAN M., 2016. Zmiany w systematyce żab zielonych (Pelophylax sp.) zachodniej Palearktyki. [W:] Wpływ odkryć Profesora Leszka Bergera na rozwój nauk biologicznych. SZAJDAK L. W., SMIEEOWSKI J. (red.). Instytut Środowiska Rolniczego i Leśnego Polskiej Akademii Nauk, Poznań, 129-138.

Kolenda K., PiETRAS-Lebioda A., Hofman S. OGIElska M., PABIJAN M., 2017. Preliminary genetic data suggest the occurrence of the Balkan water frog, Pelophylax kurtmuelleri, in southwestern Poland. Amphibia-Reptilia 38, 187-196.

LuKanov S., TZANKov N., SimeONOVSKa-NikOlOVA D., 2015. A comparative study of the mating call of Pelophylax ridibundus and Pelophylax kurtmuelleri (Anura: Ranidae) from syntopic and allotopic populations. J. Nat. Hist. 49, 257-272.

LYMBERAKIS P., POULAKAKIS N., MANTHALOU G., TSigenopoulos C. S, Magoulas A., MYlonas M., 2007. Mitochondrial phylogeography of Rana (Pelophylax) populations in the Eastern Mediterranean region. Mol. Phylogenet. Evol. 44, 115-125.

MarRacci S., Michelotti V., Guex G. D., Hotz H., Uzzell T., RAGghianti M., 2011. RrS1 like sequences of water frogs from central Europe and around the Aegean Sea: chromosomal organization, evolution, possible function. J. Mol. Evol. 72, 368-382.

MitURA A., NiEMCZUK K., ZAREBA K., ZAJAC M., LAROUCAU K., SZYMANSSKA-CZERWINSKA M., 2017. Free-living and captive turtles and tortoises as carriers of new Chlamydia spp. PLoS One 12, e0185407.

MŁYNARSKI M., SZYNDLAR Z., EsTes R., SANCHIZ B., 1984. Amphibians and reptiles from the Pliocene locality of Węże II near Działoszyn (Poland). Acta Palaeontol. Pol. 29, 209-226.

MORITZ C., 1994. Defining 'evolutionarily significant units' for conservation. Trends Ecol. Evol. 9, 373-375.

NAJBAR B., SURA P., 2018. Żółw ozdobny Trachemys scripta (Thunberg in Schoepff, 1792). [W:] Atlas płazów i gadów Polski. Status, rozmieszczenie, ochrona. GŁoWAcIŃSKI Z., SURA P. (red.). PWN, Warszawa, 115-117.

PABIJAN M., BABIK W., 2006. Genetic structure in northeastern populations of the Alpine newt (Triturus alpestris): evidence for post-Pleistocene differentiation. Mol. Ecol. 15, 2397-2407.

PABIJAN M., BABIK W., RAFIŃSKI J., 2005. Conservation units in north-eastern populations of the Alpine newt (Triturus alpestris). Conserv. Genet. 6, 307-312.

PABIJAN M., Zieliński P., DUdeK K., STUGlik M., BABIK W., 2017. Isolation and gene flow in a speciation continuum in newts. Mol. Phylogenet. Evol. 116, 1-12.

PaX F., 1921. Die Tierwelt Schlesiens. Gustav Fischer Verlag, Jena.

PAX F., 1925. Wirbeltierfauna von Schlesien. Faunistische und tiergeographische Untersuchungen im Odergebiet. Gebrüder Borntraeger Verlag, Berlin.

POLO-CAVIA N., LÓPEZ P., MARTIN J., 2011. Aggressive interactions during feeding between native and invasive freshwater turtles. Biol. Invasions 13, 1387-1396.

PROFUS P., MAJTYKA T., 2018. Rzekotka drzew na Hyla arborea (Linnaeus, 1758) i rzekotka wschodnia Hyla orientalis Bedriaga, 1890. [W:] Atlas płazów i gadów Polski. Status, rozmieszczenie, ochrona. GŁoWAcIŃSKI Z., SURA P. (red.). PWN, Warszawa, 57-60.

PROFUS P., SURA T., 2018. Ropucha zielona Bufotes viridis (Laurenti, 1758). [W:] Atlas płazów i gadów Polski. Status, rozmieszczenie, ochrona. GŁOWACIŃSKI Z., SURA P. (red.). PWN, Warszawa, 51-53.

RAPORT, 2016. Raport $z$ konsultacji publicznych oraz opiniowania projektu rozporzadzenia $\mathrm{Mi}$ nistra Srodowiska $w$ sprawie ochrony gatunkowej zwierzat, zwanego dalej "projektem”. http: / / legislacja.rcl.gov.pl/docs / /515/ 12284 754/12349740/12349741/dokument236177. pdf

ROZPORZADZENIE, 2014. Rozporzadzenie Ministra Środowiska z dnia 6 października 2014 roku $w$ sprawie ochrony gatunkowej zwierzat. Dz. U. 2014, poz. 1348

ROZPORZĄDZENIE, 2016. Rozporzadzenie Ministra Środowiska $z$ dnia 16 grudnia 2016 roku $w$ sprawie ochrony gatunkowej zwierzat. Dz. U. 2016, poz. 2183.

SANTOS J. L., ŽAGAR A., DRAŠlER K., RATO C., AYRES C., HARRIS D. J., CARRETERO M. A., SALVI D., 2019. Phylogeographic evidence for multiple long-distance introductions of the common wall lizard associated with human trade and transport. Amphibia-Reptilia. 40, 121127.

Sillero N., Campos J., Bonardi A., Corti C., CREEMERS R., CROCHET P. A., CRNOBRNJA IsAilovic J., DenoËl M., Ficetola G. F., GoNÇALVES J., KuZMin S., LYMBERAKIS P., DE POUS P., RODRIGUEZ A., SINDACO R., SPEYBROECK J., TOXOPEUS B., VIEITES D. R., VenCES M., 2014. Updated distribution and biogeography of amphibians and reptiles of Europe. Amphibia-Reptilia 35, 1-31.

SKÓRZEWSKI G., 2017. Uwagi na temat badań $i$ wystepowania padalca kolchidzkiego Anguis colchica incerta $w$ Polsce. Chrońmy Przyr. Ojcz. 73, 57-63.

Sos T., 2010. Evaluating the accuracy of morphological traits used in Anguis (sub)species differentiation. Herpetol. Romanica 4, 29-44.

SPEYBROECK J., BEUKEMA W., CROCHET P. A., 2010. A tentative species list of the European herpetofauna (Amphibia and Reptilia), an update. Zootaxa 2492, 1-27.

SPEYBROECK J., BEUKEMA W., BOK B., VAN DER VOORT J., 2016. Field guide to the amphibians and reptiles of Britain and Europe. Bloomsbury Publishing, Londyn.

StÖCK M., Moritz C., HiCKerson M., Frynta D., DUJSEBAYEVA T., EREMCHENKO V., MACEY J. R., PAPENFUSS T. J., WAKE D. B., 2006. Evolution of mitochondrial relationships and biogeography of Palearctic green toads (Bufo viridis subgroup) with insights in their genomic plasticity. Mol. Phylogenet. Evol. 41, 663-689. 
STÖCK M., Dubey S., KluTSch C., LITVINChUK S. N., SCHEIDT U., PERRIN N., 2008. Mitochondrial and nuclear phylogeny of circum-Mediterranean tree frogs from the Hyla arborea group. Mol. Phylogenet. Evol. 49, 1019-1024.

STÖCK M., DUFRESNES C., LITVINCHUK S. N., LYMBerakis P., Biollay S., BerRoneau M., BorzeE A., Ghali K., OGIElska M., Perrin N., 2012. Cryptic diversity among Western Palearctic tree frogs: Postglacial range expansion, range limits, and secondary contacts of three European tree frog lineages (Hyla arborea group). Mol. Phylogenet. Evol. 65, 1-9.

SurA P., 2018a. Padalec zwyczajny Anguis fragilis Linnaeus, 1758 i padalec kolchidzki Anguis colchica (Nordmann, 1840). [W:] Atlas płazów i gadów Polski. Status, rozmieszczenie, ochrona. GŁOWACIŃSKI Z., SURA P. (red.). PWN, Warszawa, 91-94.

SuRA P., 2018b. Murówka pospolita Podarcis muralis (Laurenti, 1768). [W:] Atlas płazów i gadów Polski. Status, rozmieszczenie, ochrona. GŁoWACIŃsKi Z., SURA P. (red.). PWN, Warszawa, $118-120$

SuRA P., 2018c. Zaskroniec rybołów Natrix tessellata (Laurenti, 1768). [W:] Atlas płazów i gadów Polski. Status, rozmieszczenie, ochrona. GŁOWACIŃSKI Z., SURA P. (red.). PWN, Warszawa, 120-122.

SZABÓ K., VÖRÖS J., 2014. Distribution and hybridization of Anguis fragilis and A. colchica in Hungary. Amphibia-Reptilia 35, 135-140.

SZYNDLAR Z., BORCZYK B., 2014. Gady (Reptilia). [W:] Fauna Polski. Charakterystyka $i$ wykaz gatunków. BOGDANOWICZ W., CHUDZICKA E., PILIPIUK I., SKIBIŃSKA E., (red.). Muzeum i Instytut Zoologii PAN, Warszawa, 215-247.

ŚWIETEK M., KWIECIŃSKI Z., KACZMARSKI M.. 2015. Żótwie czerwonolice $w$ polskich ogrodach zoologicznych $w$ latach 2005 do 2013. [W:]
Ksiażka abstraktów - III Konferencja Naukowa im. prof. dr hab. Leszka Bergera. Poznań, 30-31.05.2015, Uniwersytet Przyrodniczy w Poznaniu, Poznań, 25.

UdzIELA S., 1910. Klasa: Reptilia - gady i klasa: Amphibia - płazy. [W:] Klucz do oznaczania zwierzat kregowych ziem polskich. HOYER H. (red.). Kółko Przyrodników Uczniów Uniwersytetu Jagiellońskiego w Krakowie, Kraków, 6988.

VLČEK P., NAJBAR B., JABLONSKI D., 2010. First records of the Dice Snake (Natrix tessellata) from the North-Eastern part of the Czech Republic and Poland. Herpetol. Notes 3, 23-26.

VLČEK P., ZAVADIL V., JABLONSKI D., MEBERT K., 2011. Dice Snake (Natrix tessellata) in the Baltic Sea Drainage Basin (Karvinsko District in Silesia, Czech Republic). Mertensiella 18, 177-187.

WIENS J. J., 2008. Systematics and herpetology in the age of genomics. BioScience 58, 297307.

WILCZEK A., GROCHOWSKA M., ROMANOWSKI J., 2018. Wysteppowanie żółwia ozdobnego Trachemys scripta $w$ Warszawie. Przegl. Przyr. 29, 131-135.

Wirga M., MAJTYKa T., 2013. Records of the common wall lizard Podarcis muralis (Laurenti, 1768) from Poland. Herpetol. Notes 6, 421423.

Wirga M., MAJTYKA T., 2015a. Do climatic requirements explain the northern range of European reptiles? Common wall lizard Podarcis muralis (Laur.) (Squamata, Lacertidae) as an example. North-West. J. Zool. 11, 296-303.

Wirga M., MAJTYKA T., 2015b. Herpetofauna of the opencast mines in Lower Silesia. Fragm. Faun. 58, 65-70.

KOSMOS Vol. 68, 1, 209-221, 2019

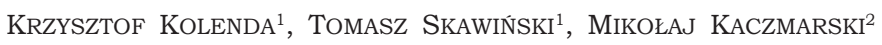

${ }^{1}$ Department of Evolutionary Biology and Conservation of Vertebrates, University of Wrockaw, 21 Sienkiewicza Str., 50-335 Wrockaw,

${ }^{2}$ Department of Zoology, Institute of Zoology, Poznan University of Life Sciences, 71c Wojska Polskiego Str., 60-625 Poznań,

E-mail: krzysztof.kolenda@uwr.edu.pl

\section{A REVIEW OF “NEW" SPECIES OF AMPHIBIANS AND REPTILES OCCURRING IN POLAND}

Summary

Several species of amphibians and reptiles new to Poland were described recently. However, data on their origin, distribution and taxonomic status are often limited and ambiguous. Here, we summarize the current state of knowledge on these species and propose some changes to the national list of protected species. The eastern tree frog and eastern slow worm are native to Poland and should be under strict and partial protection, respectively. We recommend inclusion of these species in the regional lists of protected species until the national list is updated. The status of four other taxa (Balkan frog, toad Bufotes variabilis, common wall lizard and dice snake) is uncertain and needs further study. Until the status of the dice snake is established, it should be removed from the list of protected species.

Key words: alien species, biodiversity, cryptic species, herpetofauna, species protection 
